\title{
AUTUMN MIGRATION OF THE GOLDCREST (Regulus regulus) IN WESTERN HUNGARY*
}

\author{
József Gyurácz, József Góczán, Péter Bánhidi and Ágnes Lepold
}

\begin{abstract}
Gyurácz J., Góczán J., Bánhidi P., Lepold Á. 2003. Autumn migration of the Goldcrest (Regulus regulus) in western Hungary. Ring 25, 1-2: 37-46.

At a site in Tömörd (W Hungary) in 2000-2001, numbers of Goldcrests peaked on the last days of October and the first days of November (24 Oct. - 10 Nov.). Migration of both sexes was somewhat differentiated - females migrated a little bit earlier than males. Goldcrests arriving in the peak migration periods stored significantly more fat than individuals ringed in the other periods (ANOVA: $F_{4,305}=28.6, p<0.0001$ ). The spatial occurrence of migrating Goldcrests revealed clumped distribution $-83 \%$ of the total captures took place in a dense scrubland, $17 \%$ in a grassland overgrown by bushes. During the migration there were more males - the average sex ratio in Tömörd was $1.61: 1$. These results are discussed in relation to the species' migration strategies and patterns of occurrence in northern Europe.
\end{abstract}

J. Gyurácz, J. Góczán, Department of Zoology, Berzsenyi College, Szombathely, P.O. Box 170, H-9701, Hungary; P Bánhidi, Á Lepold, Local Group of County Vas, BirdLife Hungary, Szombathely, P.O. Box 170, H-9701, Hungary

* Publication appointed to the SE European Bird Migration Network papers

Key words: Goldcrest, Regulus regulus, autumn migration, Hungary

\section{INTRODUCTION}

The Goldcrest is one of the smallest body mass birds nesting in the Palearctic region. It prefers to nest especially in coniferous forests of boreal zone and mountain ranges (Cramp 1998). In Hungary about 1000 pairs nest in West-Transdanubia and in the mid-mountains, but also significant numbers of these birds migrate through every year (Barbácsy 1983). The Goldcrest is considered as a partial migrant. The migrating part of the population spends the winter mainly in the southern parts of Europe, and also in North Africa in small numbers. The proportion of resident birds is increasing towards the south (Cramp 1998). Ringed foreign Goldcrests recovered in Hungary come from Scandinavia and the Baltic region, while Hungarian ringed birds have been recovered in Italy and Slovenia (BirdLife Hungary Ringing Centre). 
Only one paper was published about the autumn migration dynamics of the Goldcrest in Hungary (Miklay and Csörgö 1998) because of the small number of ringed birds. One of the reasons for this is that a part of the important ringing stations work in reedbeds, where Goldcrests do not occur in larger numbers. The other reason is that the stations do not go on ringing after late October or early November, when most of the northern birds migrate through Hungary. At the Tömörd Bird Ringing Station in the west of Hungary $\left(47^{\circ} 22^{\prime} \mathrm{N}, 16^{\circ} 41^{\prime} \mathrm{E}\right.$; Fig. 1) however, we

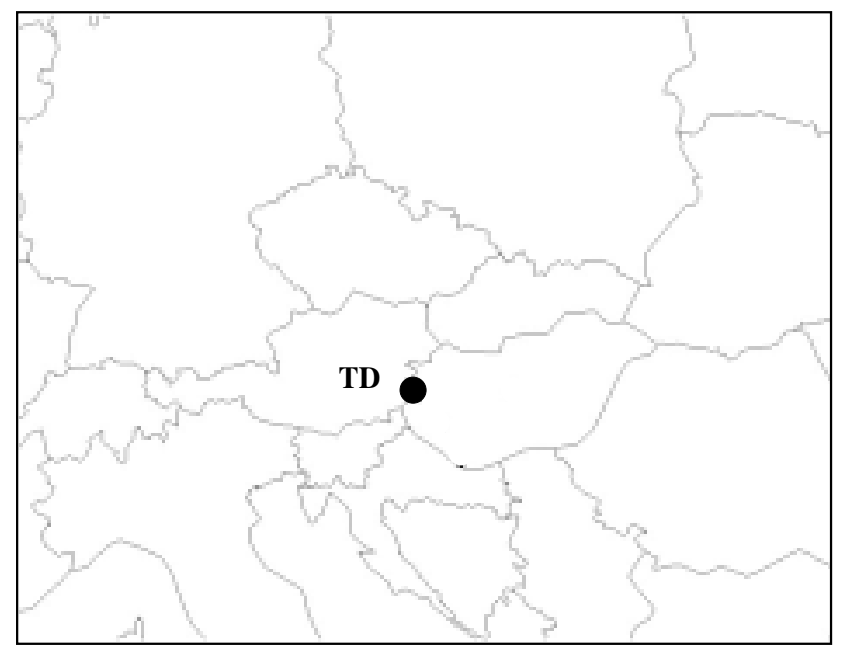

Fig. 1. Location of the Tömörd ringing site (TD)

have ringed a significant number of Goldcrests in recent years. In 1998, 124 individuals of the species were ringed, in 1999 - 112, in 2000 - 521, in 2001 - 451 and in $2002-42$. Based on the data from 2000 and 2001, a thorough analysis of the autumn migration became possible. In the examination of the data we had following goals: (1) to determine the choice of stop-over habitats by Goldcrests, (2) to describe and compare the migration dynamics of males and females based on daily captures, (3) to estimate the length of stop-over of migrating birds, (4) to describe migrating populations based on wing and tail length, (5) to examine changes in fat reserves during the season and (6) to determine the proportion of sexes.

\section{STUDY AREA AND METHODS}

The birds were captured from mid-August until mid-November in both years. 27 numbered mist-nets $(12 \times 2.5 \mathrm{~m}$ in size, four-shelf, with a mesh of $16 \mathrm{~mm})$ were set up in three different plant communities around the ringing station. These are characterised below according to SE European Bird Migration Network (SEEN) manual (Busse 2000):

Scrub-grassland (S.BH2N0.2PRCR.O.) - The 2-3 m high bushes make up compact, dense vegetation, which is dissected by small grass patches. Its characteristic 
plant species are: Prunus spinosa, Crataegus monogyna, Pyrus pyraster, Rosa canina. The majority of nets were standing in this biotop.

Weedy strip of grassland (S.BG2N9.1ROCA.O.) - It makes a transition between the wet biotopes of the swamp and the steppe communities that used to cover the croplands around. There are a few bushes in the grassland. Its characteristic plant species are: Calamagrostris epigeios, Cirsium arvense, Arrhenatherum elatius, Verbascum thapsus. There are two small patches of Sambucus ebuli. There were 8 nets in this biotop.

Swamp (S.TC1SO.O.R.) - Characteristic plants are Glyceria maxima, Typha latifolia, Salix cinerea. There was a line of 5 nets here.

Biometric data were taken using the methods of Actio Hungarica. We ringed, sexed and weighed to the nearest $0.1 \mathrm{~g}$ (using a spring balance) all birds. The wing and tail lengths were measured to the nearest $1 \mathrm{~mm}$. The fat reserves were estimated visually according to Szentendrey et al. (1979) - ranging from 0 (no fat) to 5 (bulging fat).

We checked the distribution of the captures in the different biotop types with $\chi^{2}$-test. Using the daily capture data, we constructed migration graphs and a cumulative graph for the sexes. We compared the values of daily captures for years and sexes by calculating the correlation coefficient. Based on the waves of the smoothed (by 3-day moving average) migration dynamics curve we divided the season into shorter periods. Individuals ringed within the same period were regarded as belonging to the same hypothetical population. Their average wing length, tail length, body mass and fat score were compared by using the one-way ANOVA-test and the Tukey HSD-test (Fowler and Cohen 1986).

\section{RESULTS}

The spatial occurrence of migrating Goldcrests revealed clumped distribution $\left(\chi^{2}=244.54, d f=2, p<0.05\right)-83 \%$ of the total capture occurred in dense scrubland, $17 \%$ in grassland overgrown by bushes. We did not catch any Goldcrests in swamp.

Based on the migration graphs (Fig. 2), we determined 5 migration periods in 2000 and 4 in 2001 (Table 1) - the last period in the latter year included days of IV and $\mathrm{V}$ ones in 2000. The course of the catching dynamics was very similar for both years $(r=0.985)$. The dates of the first captured birds were 24 August 2000 and 31 August 2001. The date of the last capture was 18 November for both years as this was the end of ringing. The peak period of migration fell on the last days of October. In both years we captured the largest number of Goldcrests on 28 October - 58 birds in 2000 and 110 in 2001. The most numerous periods were the III period in 2000 (we captured $28 \%$ of the birds) and the IV/V period in $2001(63 \%)$. The median dates of migration in 2000 were 22 October for males and 18 October for females, in $2001-26$ October for males and 24 October for females. The seasonal dynamics of sexes was somewhat differentiated in both years (Fig. 2). It seems that share of males increased during peak days of migration (especially in 2000). 

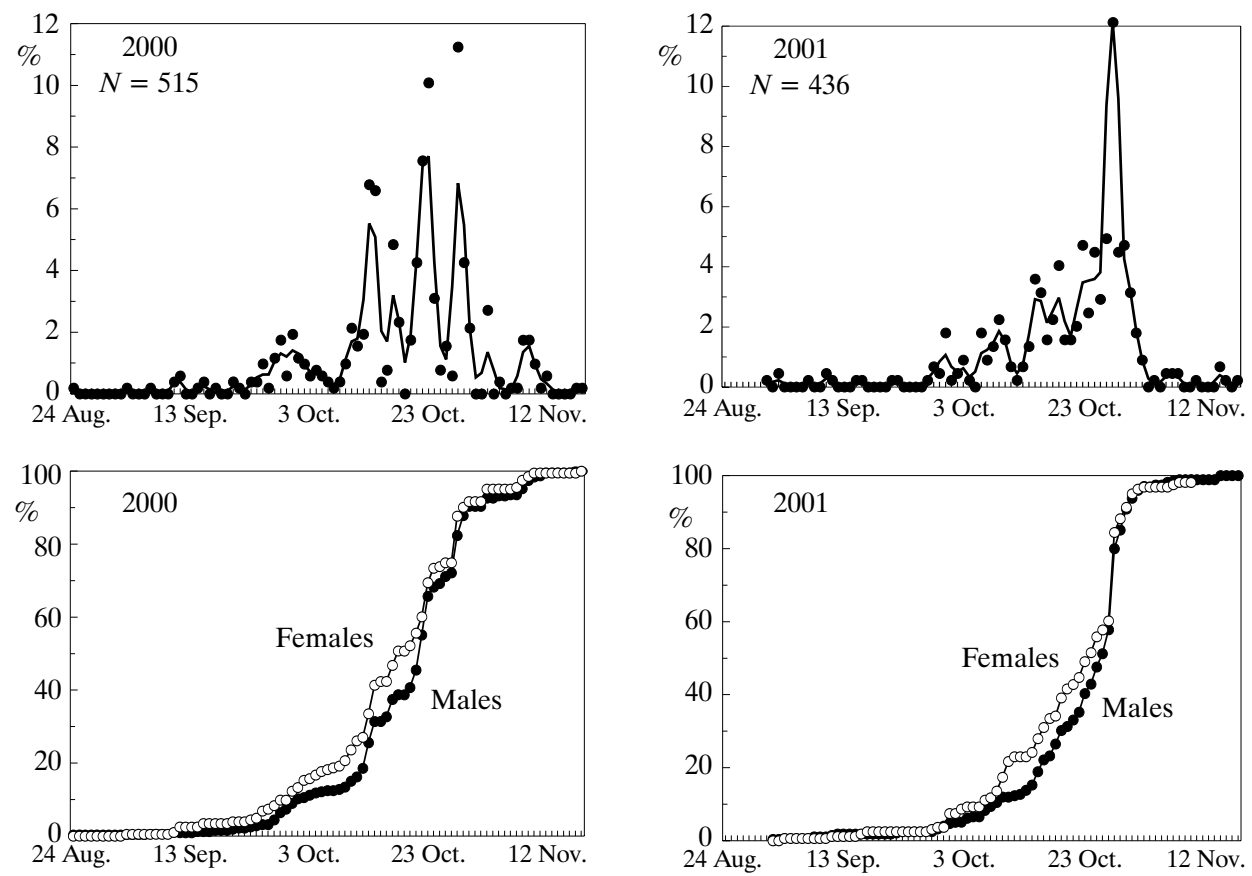

Fig. 2. Migration dynamics of Goldcrests in Tömörd in 2000 and 2001 (upper panels: dots - daily catches in percent of all individuals caught within the season; line - smoothed by 3-day moving average) and passage of both sexes (lower panels: cumulative curves)

Table 1

The migration periods in 2000 and 2001

\begin{tabular}{|c|c|c|}
\hline Period & 2000 & 2001 \\
\hline I & 24 Aug.-6 Oct. & 31 Aug.-4 Oct. \\
\hline II & 7-18 Oct. & 5-12 Oct. \\
\hline III & 19-23 Oct. & 13-21 Oct. \\
\hline IV & 24 Oct.-2 Nov. & 22 Oct.-18 Nov. \\
\hline V & $3-18$ Nov. & \\
\hline
\end{tabular}

We recaptured $5.0 \%$ of the ringed birds in the same migration season, their average length of stay was 1-2 days. During this short time no considerable fat reserves growth was found.

In wing length there was only one case of significant difference: in 2001 the wing length of females caught in the first period was significantly larger than of those migrating in the second and the last periods (one-way ANOVA: $F_{1,169}=3.22, p<0.02$, for Tukey $H S D$-test see Table 2). Significant difference in tail length was found in two cases. In 2000 the tail of females in the first period was shorter than in the last period (ANOVA: $F_{4,195}=3.29, p<0.01$, for Tukey $H S D$-test see Table 3). However, 
in 2001 the tail of females in the second period was longer than of those captured in the last period (ANOVA: $F_{3,169}=3.55, p<0.02$, for Tukey $H S D$-test see Table 3 ).

Table 2

Comparison of the average wing length of female Goldcrests captured in different periods. $M$ - mean, $S D$ - standard deviation. Tukey $H S D$-test: bold $-p<0.05$.

\begin{tabular}{|c|c|c|c|c|}
\hline 2000 & I & II & III & IV/V \\
$M \pm S D$ & $53.26 \pm 1.16$ & $51.96 \pm 1.52$ & $52.19 \pm 0.93$ & $52.09 \pm 1.54$ \\
$n$ & 15 & 23 & 32 & 103 \\
\hline I & & $\mathbf{0 . 0 3}$ & 0.07 & $\mathbf{0 . 0 2}$ \\
\hline II & & & 0.93 & 0.97 \\
\hline III & & & & 0.99 \\
\hline
\end{tabular}

Table 3

Comparison of the average tail length of female Goldcrests captured in different periods. $M$ - mean, $S D$ - standard deviation. Tukey $H S D$-test: bold $-p<0.05$.

\begin{tabular}{|c|c|c|c|c|c|}
\hline 2000 & I & II & III & IV & V \\
$M \pm S D$ & $38.43 \pm 1.71$ & $38.97 \pm 1.25$ & $39.06 \pm 1.93$ & $39.21 \pm 1.63$ & $40.4 \pm 1.50$ \\
$n$ & 40 & 65 & 47 & 38 & 10 \\
\hline I & & 0.46 & 0.36 & 0.21 & $\mathbf{0 . 0 1}$ \\
\hline II & & & 0.99 & 0.95 & 0.07 \\
\hline III & & & & 0.99 & 0.13 \\
\hline IV & & & & & 0.24 \\
\hline
\end{tabular}

\begin{tabular}{|c|c|c|c|c|}
\hline 2001 & I & II & III & IV/V \\
$M \pm S D$ & $39.20 \pm 1.26$ & $39.74 \pm 1.51$ & $39.09 \pm 1.53$ & $38.63 \pm 1.63$ \\
$n$ & 15 & 23 & 32 & 103 \\
\hline I & & 0.73 & 0.99 & 0.55 \\
\hline II & & & 0.43 & $\mathbf{0 . 0 1}$ \\
\hline III & & & & 0.46 \\
\hline
\end{tabular}

Considering body mass, we found significant difference only in 2000 within the males. Individuals in the first period were lighter than those ringed in the second period, furthermore, individuals in the second and third periods were heavier than males captured in the last period (ANOVA, $F_{4,305}=5.25, p<0.0004$, for Tukey $H S D$-test see Table 4). In both years and for both sexes we found significant differences in the amount of stored fat (Table 5 and 6). In 2000 individuals of both sexes had the least amount of fat in the first and fifth periods. Birds that migrated in the second, third and fourth periods had more fat than those in the first and fifth. The largest amount of fat was stored by males captured in the third period, more than by birds ringed in the other four periods (ANOVA: $F_{4,305}=28.6, p<0.0001$, for Tukey $H S D$-test see Table 5). In this year the situation was the same for females, the largest amount of fat was stored by birds in the third period, the value of which was 
Table 4

Comparison of the average body mass of male Goldcrests captured in different periods. $M$ - mean, $S D$ - standard deviation. Tukey $H S D$-test: bold $-p<0.05$.

\begin{tabular}{|c|c|c|c|c|c|}
\hline 2000 & I & II & III & IV & V \\
$M \pm S D$ & $5.56 \pm 0.41$ & $5.81 \pm 0.48$ & $5.71 \pm 0.40$ & $5.64 \pm 0.41$ & $5.4 \pm 0.32$ \\
$n$ & 38 & 87 & 98 & 67 & 20 \\
\hline I & & $\mathbf{0 . 0 2}$ & 0.42 & 0.92 & 0.60 \\
\hline II & & & 0.44 & 0.09 & $\mathbf{0 . 0 0}$ \\
\hline III & & & & 0.85 & $\mathbf{0 . 0 3}$ \\
\hline IV & & & & & 0.17 \\
\hline
\end{tabular}

Table 5

Comparison of the average fat score of male Goldcrests captured in different periods. $M$ - mean, $S D$ - standard deviation. Tukey $H S D$-test: bold $-p<0.05$.

\begin{tabular}{|c|c|c|c|c|c|}
\hline 2000 & I & II & III & IV & V \\
$M \pm S D$ & $1.74 \pm 1.66$ & $2.57 \pm 1.61$ & $3.91 \pm 0.99$ & $2.93 \pm 1.03$ & $1.55 \pm 1.36$ \\
$n$ & 38 & 87 & 98 & 67 & 20 \\
\hline I & & $\mathbf{0 . 0 0}$ & $\mathbf{0 . 0 0}$ & $\mathbf{0 . 0 0}$ & 0.99 \\
\hline II & & & $\mathbf{0 . 0 0}$ & 0.47 & $\mathbf{0 . 0 1}$ \\
\hline III & & & & $\mathbf{0 . 0 0}$ & $\mathbf{0 . 0 0}$ \\
\hline IV & & & & & $\mathbf{0 . 0 0}$ \\
\hline
\end{tabular}

\begin{tabular}{|c|c|c|c|c|}
\hline 2001 & I & II & III & IV/V \\
$M \pm S D$ & $1.0 \pm 0.84$ & $1.06 \pm 1.12$ & $2.71 \pm 1.61$ & $2.84 \pm 1.24$ \\
$n$ & 18 & 16 & 56 & 183 \\
\hline I & & 0.99 & $\mathbf{0 . 0 0}$ & $\mathbf{0 . 0 0}$ \\
\hline II & & & $\mathbf{0 . 0 0}$ & $\mathbf{0 . 0 0}$ \\
\hline III & & & & 0.91 \\
\hline
\end{tabular}

higher than in the first and second periods. Beside the third, females of the second and fourth periods stored more fat than individuals in the first period, when the least fat reserves were found (ANOVA: $F_{4,198}=10.8, p<0.0001$, for Tukey $H S D$-test see Table 6). In 2001 the situation for the males (ANOVA: $F_{3,269}=18.91, p<0.0001$, for Tukey $H S D$-test see Table 5) was the same as for the females (ANOVA: $F_{3,169}=13.05, p<0.0001$, for Tukey $H S D$-test see Table 6). Individuals arriving in the third and fourth periods stored more fat than individuals ringed in the first and second periods.

The sex composition of Goldcrests captured in the seasons in question is shown in Table 7. 
Table 6

Comparison of the average fat score of female Goldcrests captured in different periods. $M-$ mean, $S D$ - standard deviation. Tukey $H S D$-test: bold $-p<0.05$.

\begin{tabular}{|c|c|c|c|c|c|}
\hline 2000 & I & II & III & IV & V \\
$M \pm S D$ & $1.78 \pm 1.73$ & $2.76 \pm 1.78$ & $3.68 \pm 0.88$ & $3.34 \pm 1.11$ & $2.4 \pm 1.07$ \\
$n$ & 40 & 65 & 47 & 41 & 10 \\
\hline I & & $\mathbf{0 . 0 1}$ & $\mathbf{0 . 0 0}$ & $\mathbf{0 . 0 0}$ & 0.74 \\
\hline II & & & $\mathbf{0 . 0 1}$ & 0.15 & 0.94 \\
\hline III & & & & 0.95 & 0.08 \\
\hline IV & & & & & 0.25 \\
\hline
\end{tabular}

\begin{tabular}{|c|c|c|c|c|}
\hline 2001 & I & II & III & IV/V \\
$M \pm S D$ & $1.07 \pm 0.96$ & $1.78 \pm 1.31$ & $3.12 \pm 1.51$ & $2.94 \pm 1.34$ \\
$n$ & 15 & 23 & 32 & 103 \\
\hline I & & 0.38 & $\mathbf{0 . 0 0}$ & $\mathbf{0 . 0 0}$ \\
\hline II & & & $\mathbf{0 . 0 0}$ & $\mathbf{0 . 0 0}$ \\
\hline III & & & & 0.91 \\
\hline
\end{tabular}

Table 7

Share of sexes within caught Goldcrests

\begin{tabular}{|c|c|c|c|c|c|}
\hline & Males & $\%$ & Females & $\%$ & Rate of males/females \\
\hline 2000 & 312 & 60.6 & 203 & 39.4 & $1.54: 1$ \\
\hline 2001 & 275 & 63.1 & 161 & 36.9 & $1.71: 1$ \\
\hline Total & 587 & 61.7 & 364 & 38.3 & $1.61: 1$ \\
\hline
\end{tabular}

\section{DISCUSSION}

Our observations showed that the area around Tömörd is an important stopover site for Goldcrests migrating through our country during the autumn season. This was proved by the relatively large number of captured birds. Goldcrests that interrupted their migration in Tömörd preferred to choose the scrubby plant community (Prunus spinosa, Crataegus monogyna, Pyrus pyraster) which provided a safe shelter from the Sparrow Hawk (Accipiter nisus) - a frequent raptor in the area. Lindström (1990) observed similar habitat choice by Bramblings (Fringilla montifringilla) in order to avoid predation. For feeding and energy restoring, the scrubs of Tömörd cannot have been very important, which we presume on the basis of the small scale of recaptured migrants within the same ringing season and the short length of their stay (1-2 days) here.

The Goldcrest is considered as a partial migrant. Except for the most northern breeding areas there are wintering birds staying behind everywhere (Hilden 1982, Hogstad 1984). The majority of the population migrates - birds spend the winter in the central and southern parts of Europe. The autumn migration dynamics in Hun- 
gary was studied at a site in Ócsa (central Hungary) only (Miklay and Csörgő 1998), but there are detailed data available from the eastern and southern Baltic Basin (Remisiewicz and Baumanis 1996). In this region, similarly to the results in Tömörd, the annual number of birds captured during autumn migration showed considerable oscillation, which is usually not connected with the changes in the size of populations, but with the occasional changes of migration routes as well as of stop-over and feeding sites. In the Baltic region the migration of Goldcrests lasts from early September until late October (Remisiewicz and Baumanis 1996), the peak season in Poland falls in early October. In Scandinavia the migration of Goldcrests starts in late August and lasts into early November, with the peak period from late September to mid-October (Karlsson 1980, Cramp 1998). In Hungary the migration is significantly shorter, it takes place from late September until the first days of November, the peak period falling on the last days of October and the first days of November (24 Oct. - 10 Nov.) in the studied years. This is because Scandinavian and Baltic Goldcrests arrive in great numbers at that time. Recovery data also support this. In Tömörd a bird from Russia, ringed in the Rybachy station (Courish Spit, Baltic Sea), fell into the net on 11 November 2001.

According to our observations, the females migrate a little bit earlier than the males. Miklay and Csörgő (1998) showed that males and females migrate together and their migration takes place extremely quickly (especially if compared to their size), because of efficient fat accumulation (Petterson and Hasselquist 1985). We know of a bird that was recaptured one day after it was ringed at a place $444 \mathrm{~km}$ away, but several others have been reported to have flown $250-800 \mathrm{~km}$ in one day (Ellegren 1993). They cover the largest distances at night. It has been observed near the Baltic Sea that in high-pressure weather situations the migration activity of Goldcrests increased considerably. The height of flying depended especially on the direction of wind and its force - in a heavy headwind Goldcrests migrated at a lower height. On the other hand, it can be said that the migration of the Goldcrest depends much less on the weather than that of other passerines. At a Polish ringing station intensive migration was observed in heavy wind and rain, too (Remisiewicz and Baumanis 1996).

The migration of Goldcrests is a so-called gradual migration, that is, the individuals of populations nesting further north start their migration earlier and migrate faster than those nesting more towards the south (Cramp 1998). On migration graphs the waves usually have one distinct peak, which indicates that these individuals might come from the same nesting population. Sometimes we can find more than one peak within the same wave, which suggests possible mingling of the populations. We regard this probable, based on our observations of wing and tail length, according to which the average wing and tail length of birds captured within the same migration periods do not differ significantly except for a small part of the females. However, it is also possible that there is no essential divergence between different populations of the Goldcrest in this respect. 
The least amount of fat was stored by birds captured in late August and early October. These individuals can probably be considered as resident birds from the local population (in the Kõszeg mountains) or short-distance migrants, and that is why they did not need to accumulate large fat-reserves. Resident individuals have been recaptured several times in the area during the migration season. We found relatively little fat also in the last migration period - on the individuals ringed in November, which could have been partly resident birds and partly migrants arriving from the north, but not going further south. So they did not need a considerable amount of fat, either. In the peak migration period (i.e. in late October and early November) Goldcrests occurring near Tömörd had a relatively large amount of fat. These birds interrupted their migration for only 1-2 days, as they had enough reserves to reach the wintering sites towards the south. However, the fat score of these birds was significantly lower than it had probably been at the beginning of their migration. According to an observation in the Baltic region, the average body mass of the Goldcrests that were ready for migration was $7.8 \mathrm{~g}$ (Remisiewicz and Baumanis 1996). In Tömörd we did not find a single bird with such big body mass among more than one thousand Goldcrests.

Observations of the sex rate in different parts of Europe during the autumn migration season reveal that the further south we go along the migration route, the larger is the proportion of males (Miklay and Csörgö 1998). This could be explained by the strong competition within the species among Goldcrests during even migration (Hansson and Pettersson 1989). The larger and more aggressive males get more food, so their death rate is lower than that of the females in resident populations as well as in the autumn-migrant populations. The data of the Tömörd observations fit this tendency. In the autumn migration season the proportion of males in Norway was $57.4 \%$ (Lifjeld 1982), in Tömörd, according to the present observation, it was $61.7 \%$, in southern Italy in winter it was $62.7 \%$ (Scebba and Lövei 1986). In Poland, in autumn males constitute $58-61 \%$ of migrants, but during spring migration the share of males is surprisingly low $-42.6-50.7 \%$ in a first migration wave and 19.6-20.2\% in a second wave (Busse and Machalska 1969). These authors suggested that changes in the sex ratio during a season indicated the borders between populations passing through the station.

In order to reveal further details about the autumn migration of Goldcrests such as e.g. age-dependency of the migration, and to get to know the wintering sites more precisely, we would like to continue our research.

\section{ACKNOWLEDGEMENTS}

We wish to express our gratitude to the members of the BirdLife Hungary who helped us in the fieldwork. J. Gyurácz was supported by György Békésy postdoctoral scholarship from Ministry of Culture and Education. 


\section{REFERENCES}

Barbácsy Z. 1983. [Goldcrest.] In: Haraszthy L. (Ed.). [Breeding Birds in Hungary.] Natura Press, Budapest: pp. 196-197. (in Hungarian).

Busse P. 2000. Bird Station Manual. SEEN, Univ. of Gdańsk, Gdańsk.

Busse P., Machalska J. 1969. Instability of sex composition of migrating Goldcrests. Not. Orn. 10: 21-31. Cramp S. 1998. The Complete Birds of the Western Palearctic. CD-ROM, Oxford Univ. Press, Oxford.

Ellegren H. 1993. Speed of migration and migratory flight lenghts of passerine birds ringed during autumn migration in Sweden. Ornis Scand. 24: 220-228.

Fowler J., Cohen L. 1986. Statistics for ornithologists. BTO Guide No. 22, British Trust for Ornithology, Thetford.

Hansson M., Petterson J. 1989. Competition and fat deposition in Goldcrests (Regulus regulus) at a migration stop-over site. Vogelwarte 35: 21-31.

Hilden O. 1982. Winter ecology and partial migration of the Goldcrest (Regulus regulus) in Finland. Ornis Fenn. 59: 99-122.

Hogstad O. 1984. Variation in numbers, territoriality and flock size of a Goldcrest (Regulus regulus) population in winter. Ibis 126: 296-306.

Karlsson L. 1980. The autumn migration of the Goldcrest (Regulus regulus) at Falsterbo. Anser 19: 139-146.

Lifjeld J. 1982. Sex ratio of Goldcrest (Regulus regulus) on autumn migration. Cinclus 5: 36-39.

Lindström A. 1990. The role of predation risk in stop-over habitat selection in migrating Bramblings Fringilla montifringilla. Behav. Ecol. 1, 2: 102-106.

Miklay Gy., Csörgő T. 1998. What controls the sex ratio of Goldcrests (Regulus regulus)? Ornis Hungarica 8, Suppl. 1: 79-86.

Petterson J., Hasselquist D. 1985. Fat deposition and migration capacity of Robins (Erithacus rubecula) and Goldcrest (Regulus regulus) at Ottenby, Sweden. Ring. \& Migr. 6: 66-76.

Remisiewicz M., Baumanis J. 1996. Autumn migration of Goldcrest (Regulus regulus) at the eastern and southern Baltic coast. Ring 18, 1-2: 3-36.

Scebba S., Lövei G.L. 1986. Winter residence, sex ratio and wing shape of Goldcrests (Regulus regulus) and Firecrests (R. ignicapillus) on a southern Italian island. Vogelwarte 33: 220-225.

Szentendrey G., Lövei G., Kállay Gy. 1979. Az "Actio Hungarica” madárgyûrûzótábor mérési módszerei. Állattani Közlemények 66: 161-166. 